\title{
Development of Sorption Database (KAERI-SDB) for the Safety Assessment of Radioactive Waste Disposal
}

\section{방사성페기물 처분안전성 평가 자료 제공을 위한 핵종 수착 데이터베이스 (KAERI-SDB) 개발}

Jae-Kwang Lee*, Min-Hoon Baik and Jongtae Jeong

Korea Atomic Energy Research Institute, 989-111 Daedeokdaero, Yuseong-gu, Daejeon

이재광*, 백민훈, 정종태

한국원자력연구원, 대전광역시 유성구 대덕대로 989번길 111

(Received October 16, 2012 / Revised January 22, 2013 / Approved January 31, 2013)

Radionuclide sorption data is necessary for the safety assessment of radioactive waste disposal. However the use of sorption database is often limited due to the accessability. A web-based sorption database program named KAERI-SDB has been developed to provide information on the sorption of radionuclides onto geological media as a function of geochemical conditions. The development of KAERI-SDB was achieved by improving the performance of pre-existing sorption database program (SDB-21C) developed in 1998 and considering user's requirements. KAERI-SDB is designed that users can access it by using a web browser. Main functions of KAERI-SDB include (1) log-in/member join, (2) search and store of sorption data, and (3) chart expression of search results. It is expected that KAERI-SDB could be widely utilized in the safety assessment of radioactive waste disposal by enhancing the accessibility to users who wants to use sorption data. Moreover, KAERI-SDB opened to public would also improve the reliability and public acceptance on the radioactive waste disposal programs.

Key words: Database, Radioactive waste disposal, Radionuclide, Safety assessment, Sorption

방사성폐기물 처분 안전성 평가를 위하여 방사성 핵종의 수착특성에 대한 정보제공이 필요하다. 그러나 우리나라는 최근 까지 핵종 수착 데이터베이스에 대한 접근성이 취약하여 이용에 제한이 있었다. 사용자들에게 효율적인 방법으로 핵종 수착 관련 정보를 제공하기 위해 윕을 기반으로 하는 핵종 수착 데이터베이스(KAERI-SDB)를 개발하였다. KAERI-SDB를 개발하기 위하여 1998년에 개발된 수착 데이터베이스 프로그램인 SDB-21C을 분석하고 사용자 요구사항을 반영하였으며, 사용자가 웹 브라우저를 통하여 실시간으로 수정 및 보완된 핵종 수착 자료에 실시간으로 접근이 가능하도록 구성하였다. KAERI-SDB는 로그인/회원가입, 자료 검색 및 저장 그리고 검색결과에 대한 차트 구현 등의 기능들이 포함되도록 고안되었다. KAERI-SDB 는 수착 자료를 이용하고자 하는 이용자들의 접근성을 향상함으로써 방사성폐기물 처분 안전성 평가에 폭넓게 활용될 것으 로 예상된다. 나아가, 핵종 수착관련 자료들을 일반인에게 공개함으로써 방사성폐기물 처분 프로그램에 대한 신뢰도와 대중 수용성을 증진시킬 수 있을 것으로 기대된다.

중심단어: 데이터베이스, 방사성폐기물 처분, 방사성핵종, 수착, 안전성 평가

*Corresponding Author. E-mail: jklee1@kaeri.re.kr, Tel: +82.42.868.4918 


\section{1. 서 론}

방사성폐기물 처분장에서 지하환경에 처분된 방사성폐기 물은 오랜 시간이 경과하면 결국 방사성폐기물 처분장에 유 입된 지하수와 접촉하고 지하수와 접촉한 방사성폐기물은 지하수에 용해될 것이다. 폐기물로부터 용해된 방사성 핵종 들은 인공방벽을 통과한 후, 지하수 흐름을 따라 주위 암반 균열을 통하여 생태계로 유출될 것이다. 유출된 핵종들은 지하 환경에서 이류, 분산, 확산 및 이들의 상호작용에 기인 하는 이동과정과 수착, 침전, 확산, 여과 등의 다양한 물리화 학적 지연과정에 영향을 받으며 거동하게 된다. 다양한 지 연과정 중에서 수착(收着, sorption)은 핵종의 이동을 지연 시키는 중요한 기작으로 알려져 있다[1]. 따라서 방사성핵종 의 수착특성 자료는 방사성폐기물 처분 안전성 평가 측면에 서 매우 중요하게 다루어지는 부분이다.

핵종의 수착을 실험적으로 표현하는 수착 분배계수 (Distribution Coefficient, $K_{d}$ )는 방사성폐기물의 지질학적 처분 에 대한 안전성 평가에 입력인자로 사용되며, 평형상태의 가 역적인 수착을 가정하여 사용되어 왔다. $K_{d}$ 는 측정된 단일 실험 조건에 한하여 그 수치가 유효하므로 다양한 지화학적 조건에서 방사성핵종의 $K_{d}$ 값 측정에 대한 연구들이 다수 수 행되어 왔다[2-5]. $K_{d}$ 는 용액에 존재하는 핵종과 매질간의 반응은 용액에 존재하는 핵종의 농도와 매질에 수착된 핵종 의 농도 비로 표현하며 다음 식과 같이 정의한다[6].

$$
K d=\frac{C_{s}}{C_{q}} F=\frac{\left(C_{0}-C_{q}\right)}{C_{q}} \times\left(\frac{V}{M}\right)
$$

여기서, $C_{0}$ 는 핵종의 초기농도(mole/L 또는 $\left.B q / \mathrm{mL}\right), C_{q}$ 는 수착반응 후 수용액에서의 핵종농도(mole/L 또는 $B q$ / $\mathrm{mL}), C_{s}$ 는 단위 고체질량에 수착된 핵종농도(mole/g 또는 $B q / \mathrm{g}), V$ 는 용액의 부피 $(\mathrm{mL})$, 그리고, $M$ 은 수착반응에 사 용된 고체매질의 질량 $(\mathrm{g})$ 을 의미한다. $F$ 는 $C_{q}$ 의 단위를 $\mathrm{mole} / \mathrm{L}$ 로 사용할 경우 $K_{d}$ 값을 $\mathrm{L} / \mathrm{g}$ 에서 $\mathrm{mL} / \mathrm{g}$ 으로 바꾸는 단위 환산인자로 $(F=1000) C_{q}$ 의 단위를 $\mathrm{Bq} / \mathrm{mL}$ 를 사용할 경우 $F=1$ 이다.

방사성핵종의 수착은 수소이온농도, 산화환원전위, 이온 강도, 용존 유기물, 탄산염 농도, 핵종 농도, 반응시의 고체액체 비율 등의 다양한 지화학적 조건에 따라 매우 복잡하 게 거동한다[7]. 수착반응은 이렇게 다양한 인자들의 복합적 인 요소에 의하여 영향을 받으므로 실험을 통하여 얻은 특정 조건에 대한 핵종의 수착 분배계수는 처분환경의 복잡한 지 화학적 조건에 대한 수착 특성을 규정하기는 어렵지만, 이를
적용할 수 있는 특정한 환경에서는 매우 중요한 의미를 가진 다. 하지만 문헌 등의 자료를 통해서 축적한 방대한 수착시 험 결과들로부터 원하는 지화학적 조건에 맞는 수착 자료를 검색하는 것은 상당히 어려운 작업이다. 따라서 방대한 수 착 자료에서 특정 지화학적 조건에 대한 자료를 추출하기 위 한 도구가 필요하다.

핵종수착의 중요성을 인식하여 $\mathrm{OECD/NEA}$ 의 SDB(Sorption Database)[8], 독일의 RES3-T[9] 그리고 일본의 JAEA-SDB[10] 등 선진국에서 다양한 형태의 수착 데이터베이스가 개발되었 으며, 우리나라도 핵종 수착 데이터베이스 프로그램인 SDB$21 \mathrm{C}$ 를 개발하였다. 그러나 방사성폐기물 처분 안전성 평가 측면에서 볼 때, 적절한 데이터를 선정하여 활용하기 위해서 는 핵종 수착 데이터베이스에 접근이 용이해야 하고 관련 자 료 검색이 가능해야 한다. 또한, 검색한 정보의 정확도를 확 인 할 수 있는 통계정보가 수반되어야 한다. 그러나 최근까지 개발된 핵종 수착 데이터베이스는 접근 및 검색이나 통계처 리가 취약한 상황이었다. 따라서 데이터베이스를 정확하고 효율적으로 관리할 수 있는 방법이 절실히 요구되고 있다.

기존 데이터베이스 프로그램의 관리/검색 기능을 분석 및 보완하고 사용자들에게 보다 효율적인 방법으로 핵종 수착 관련 정보를 제공하기 위해 웹 기반으로 운용되는 데이터베 이스 시스템의 필요성이 대두되었다. 본 연구에서는 사용자 의 다양한 요구를 반영한 웹기반 핵종 수착 데이터베이스 프 로그램인 KAERI-SDB를 개발하여 사용자들에게 수착 자료 를 제공하도록 하였다.

\section{2. 국내외 핵종 수착데이터베이스 현황}

방사성폐기물 처분 안전성 평가 입력 자료로 활용되는 수 착 분배계수는 지화학적 인자에 따라 매우 다양하게 분포한 다. 따라서 기존에 축적된 방대한 수착 자료로부터 다양한 처분 환경 조건에 부합하도록 자료들을 신속하고 정확하게 추출해 내는 방법이 요구된다. 본 절에서는 우리나라뿐만 아니라, 해외 기관들에서 수착 자료를 검색하고 추출해 내기 위하여 그동안 개발된 수착 데이터베이스에 대하여 기술하 였다. 국내외에서 개발된 다양한 수착 데이터베이스에 대한 내용을 Table 1에 요약하였다.

\section{1 해외 수착 데이터베이스 현황}

\subsubsection{OECD/NEA}

경제협력개발기구(Organization for Economic Coopera- 
Table 1. Status for the development of sorption databases

\begin{tabular}{|c|c|c|c|c|}
\hline $\begin{array}{l}\text { Organiza- } \\
\text { tion }\end{array}$ & DB Name & Year & $\begin{array}{l}\text { Kd } \\
\text { data }\end{array}$ & Characteristics \\
\hline NEA & NEA-SDB & 1991 & 11,000 & $\begin{array}{l}\text { - Developed in } 1991 \text { by gathering } \\
K d \text { data from co-operational } \\
\text { organizations by OECD/NEA } \\
\text { - Not updated since } 1991\end{array}$ \\
\hline $\begin{array}{c}\text { FZK } \\
\text { (Germany) }\end{array}$ & RES $^{3}-\mathrm{T}$ & 2002 & - & $\begin{array}{l}\text { - Applicable to } 6 \text { kinds of } \mathrm{TSM}^{(1)} \\
\text { - Limitted to apply TSM } \\
\text { due to the lack of data }\end{array}$ \\
\hline $\begin{array}{c}\text { JAEA } \\
\text { (Japan) }\end{array}$ & JAEA-SDB & 31999 & 24,000 & $\begin{array}{l}\text { - Opened in a form of MS access } \\
\text { in } 2003 \\
\text { - Opened a new web version DB } \\
\text { in } 2009 \\
\text { - Listed } K d \text { data for } 58 \text { elements } \\
\text { including } 22 \text { elements as key } \\
\text { radiuclides }\end{array}$ \\
\hline $\begin{array}{l}\text { Nagra } \\
\text { (Switzer } \\
\text { land) }\end{array}$ & - & 1996 & - & $\begin{array}{l}\text { - Published reports for LILW' } \\
\text { and } \mathrm{HLW}^{(2)} \text { in } 1997 \\
\text { - Solid phase: cement, near field, } \\
\text { bentonite, host rock }\end{array}$ \\
\hline $\begin{array}{l}\text { KAERI } \\
\text { (Korea) }\end{array}$ & SDB-21C & 1998 & 13,000 & $\begin{array}{l}\text { - Listed 2,000 of Kd data } \\
\text { produced by KAERI } \\
\text { - Applicable to parametric } \\
\text { model }\end{array}$ \\
\hline
\end{tabular}

※ (1) Thermodynamic sorption models

(2) Low and intermediate level radioactive waste

(3) High level radioactive waste

tion and Development, OECD) 산하 원자력기구(Nuclear Energy Agency, NEA)는 미국의 Pacific Northwest National Laboratory에서 개발한 국제 수착 자료 검색시스템(International Sorption Information Retrieval System, ISIRS)을 대체 하기 위하여 1981년 NEA 수착 데이터베이스(NEA Sorption Database, NEA-SDB)를 개발하였다[8]. NEA-SDB는 dBASE III plus를 이용하여 MS DOS 운영체제에서 구동이 되도록 고안되어 11,000 여개의 자료가 입력되었으며, 개발 당시 가 장 많은 수착 분배계수를 수록하였다. NEA-SDB는 단열충 전관물, 조암광물, 완충재 후보물질, 콘크리트/시멘트, 점 토, 응회암, 사암, 화강암 등의 다양한 지질학적 물질에 대 한 넵투늄, 라듐, 셀레늄, 스칸듐, 스트론튬, 아메리슘, 아이 오딘, 우라늄, 코발트, 테크네튬, 플루토늄 등을 포함한 30여 종 핵종들의 수착분배계수를 수록하고 있다. NEA-SDB는 흡착 등온식 계산이나 비선형 회귀방정식 등의 수학적 계산 을 할 수 있는 장점이 있다. 그러나 이러한 장점에도 불구하 고 조작이 어렵고, 초기 개발 시점 이후 수착 자료가 추가 수 록되지 않아 현재는 널리 사용되지 않고 있다.

\subsection{2 독일}

독일은 MS Access를 기반으로 하는 수착 데이터베이스
(Rossendorf Expert System for Surface and Sorption Thermodynamics, RES 3 -T)를 2002년에 개발하였다[9]. RES 3 -T는 단순히 수착 분배계수를 추출해 내던 기존 데이터베이스와 는 달리 열역학적 수착모델의 하나인 표면 착화반응 모델 (Surface Complexation Models, SCMs)의 적용이 가능하도록 고안되었다. $\mathrm{SCMs}$ 는 표면의 화학반응을 용액 조건의 변화에 독립적인 일련의 의사-열역학 상수(Quasi-thermodynamic Constants)로 표현하기 때문에 $\mathrm{K}_{\mathrm{d}}$ 모델과는 달리 화학적 조 건의 변화나 그에 따른 수용액상의 화학종 분포 변화를 충분 히 반영할 수 있다[11]. RES ${ }^{3}$-T에 적용된 SCMs는 비정전기적 모델[12], 확산 이중층 모델[13], 일정 용량 모델[14], 삼중층 모 델[15], Stern 모델[16] 그리고, 1-pK 모사[17]/MUSIC[18]/CDMUSIC[19] 등이 있다. RES ${ }^{3}-\mathrm{T}$ 에는 100 여 개의 광물에 대한 자 료와 1,000 여 개의 광물 표면 수화반응 자료, 그리고, 2,600 여 개의 표면 착물 형성상수가 수록되었다[9]. RES ${ }^{3}-\mathrm{T}$ 는 열역학 적 관점에서 수착 메커니즘을 표현하는 장점이 있음에도 불 구하고, 방사성폐기물 처분 관점에서 중요한 악틴족 핵종들 의 열역학적 상수에 대한 자료가 부족하고, 복합광물의 모델 평가에 필요한 석영, 장석, 휘석, 각섬석, 감람석 등의 조암광 물에 대한 자료가 부족한 단점이 있다.

\section{1 .3 일본}

일본 원자력연구개발기구(Japan Atomic Energy Agency, $\mathrm{JAEA}$ )는 방사성폐기물의 지질학적 처분에 대한 안전성 평 가를 위하여 열역학 데이터베이스, 확산 데이터베이스, 수 착 데이터베이스를 개발하였다[10]. JAEA 수착 데이터베이 스(JAEA-SDB)는 고준위폐기물 처분 관점에서 중요한 공학 적 방벽과 암석과 같은 천연방벽에 관한 수착 자료를 수록 하였다. JAEA-SDB는 2003년 MS-Access 버전으로 개발되었 으며, 수착 자료를 정기적으로 꾸준히 추가로 수록하여 현재 는 약 24,000 여 개의 수착 자료를 수록하고 있다. 2009년도 에는 기존의 MS-Access 버전 외에 웹 버전을 일반에 공개하 여 데이터베이스의 활용도를 증대시켰다[20]. 현재 공개된 JAEA-SDB는 고준위폐기물 처분 성능평가와 관련한 22개 주 원소와 초우라늄(Transuranium, TRU) 폐기물 처분과 관련 된 15 개 원소에 대한 수착 자료가 수록되어 있다.

\section{2 국내 수착 데이터베이스 현황}

해외에서 다양한 수착 데이터베이스가 개발되었음에도 불 구하고 우리나라의 처분환경에 부합하는 수착 자료가 없기 때문에 수착 데이터베이스의 사용에 어려움이 있었다. 이에 
우리나라도 방사성폐기물 처분 안전성 평가에 사용할 목적 으로 수착 데이터베이스를 한국원자력연구원에서 1998년도 에 SDB-21C라는 명칭으로 최초 개발하였다[21]. SDB-21C에 는 한국원자력연구원에서 자체 생산한 수착 자료와 NEA에 서 제공받은 자료가 수록되었다. SDB-21는 검색기능, 표 및 그래프 기능, 데이터 입력 기능 그리고, 3 차원 그래프 생성 기능 등을 포함하고 있다. 그러나 데이터베이스의 접근성이 좋지 않으며 검색한 수착 자료의 범위 및 평균값 등을 확인 할 수 있는 통계기능이 취약한 단점이 있다.

\section{3. 웹 기반 핵종 수착 데이터베이스 (KAERI-SDB)}

\subsection{KAERI-SDB 개발}

기존의 수착 데이터베이스 프로그램인 SDB-21C 시스템 은 사용자 컴퓨터에 해당 프로그램을 설치해야 사용이 가능 하므로 핵종 수착 자료의 추가 및 변경된 자료를 사용자에게 신속하게 전달하기 어려운 단점이 있었다. 이러한 단점을 보 완하고자 SDB-21C를 개선하여 사용자가 인터넷 웹브라우 저를 이용하여 수착 데이터베이스 시스템에 접근할 수 있도 록 웹 기반 핵종 수착 데이터베이스 프로그램인 KAERI-SDB 를 개발하였다. KAERI-SDB는 인터넷 웹브라우저를 통하여 원격에서 접속하므로 사용자의 컴퓨터에 별도의 프로그램 설치 없이 핵종 수착 자료를 검색하고 저장하는 것이 가능 하다. SDB-21C와 KAERI-SDB의 차이점을 Table 2에 정리하 였다. KAERI-SDB는 웹 기반 형식으로 인터넷 웹브라우저로 URL에 접속하므로 접근성이 좋아 관리자 또는 사용자가 관 련 정보를 확인하거나 관리하는 것이 용이하다는 장점이 있 다. 또한, 24 시간 무상정지 시스템을 제공하고, 데이터베이 스 프로그램을 추가 개발하거나, 개발된 내용을 구현하고 적

Table 2. Comparison between SDB-21C and KAERI-SDB

\begin{tabular}{ccc}
\hline Features & SDB-21C & KAERI-SDB \\
\hline $\begin{array}{c}\text { Operational system } \\
\begin{array}{c}\text { Databe management } \\
\text { system }\end{array}\end{array}$ & $\begin{array}{c}\text { Microsoft access } \\
\text { database }\end{array}$ & No limitation \\
\hline Server & None & $\begin{array}{c}\text { Linux 2.1 or more } \\
\text { recent system }\end{array}$ \\
\hline Web application server & None & TOMCAT 5.0 \\
\hline Web-browser & None & No limitation \\
\hline Accessibility & $\begin{array}{c}\text { Accessible only } \\
\text { after installation of } \\
\text { program }\end{array}$ & $\begin{array}{c}\text { Accessible to URL } \\
\text { without program } \\
\text { installation }\end{array}$ \\
\hline
\end{tabular}

용할 때 시스템의 중단 없이 서비스가 가능한 장점이 있다. KAERI-SDB의 개발을 위한 첫 번째 단계로 사용자의 요구 사항을 분석하고 기존 데이터베이스를 분석하였다. 두 번째 단계로는 데이터베이스 서버를 구축함과 동시에 데이터베 이스 프로그램을 개발하였다. 마지막 단계로 핵종 수착 자료 를 업데이트하고 서버를 시운전 한 후, KAERI-SDB를 웹브 라우저에 공개하였다. KAERI-SDB의 개발 흐름도를 Fig. 1 에 도식화하여 나타내었다. KAERI-SDB는 사용자가 웹브라 우저를 이용하여 데이터베이스 시스템에 접속하므로 사용 자가 별도의 프로그램 설치 없이 핵종 수착 자료의 검색 및 저장이 가능하도록 구성되었다. KAERI-SDB는 네트워크에 연결되어 국내외 원자력 관련 종사자 및 일반인들에게 핵종 수착 데이터베이스 정보를 네트워크를 통해 제공하게 된다. 이를 통하여 관리자가 새로운 수착 자료를 데이터베이스에 추가하면 사용자는 웹 화면에서 변경된 정보를 실시간으로 확인할 수 있게 된다. 이러한 시스템은 종전의 시스템과 달 리 사용자의 컴퓨터에 추가적인 프로그램을 설치하지 않아 도 되고, 새로운 자료들을 사용자가 별도로 갱신하지 않아도 되는 장점을 가지고 있다.

\section{2 핵종 수착 자료}

국내 처분환경에 부합되는 자료가 부족하고 해외의 핵종 수착 데이터베이스의 사용상 어려움으로 인하여 SDB-21C 가 개발되었음에도 불구하고 그 사용이 미미하였다. 특히, SDB-21C에는 대부분 OECD/NEA의 자료가 수록되어 있으 므로 국내 처분환경에 부합되는 수착 자료를 제공하는 것 이 어려웠다. 이를 보완하기 위하여 KAERI-SDB에는 12,000 여 개의 NEA 수착데이터베이스 수록 자료 외에 4,000 여 개

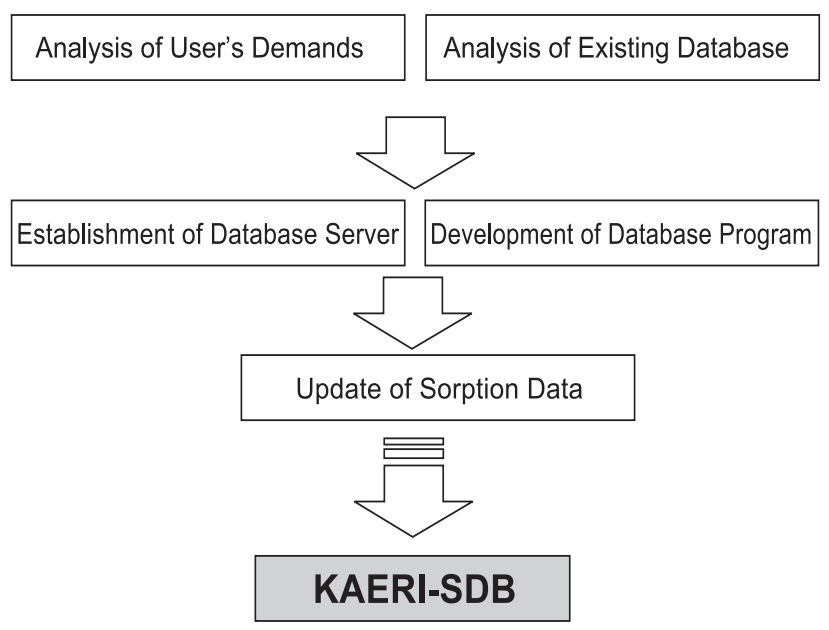

Fig. 1. Schematic diagram for the development process of KAERI-SDB. 
의 한국원자력연구원 자체생산 자료 및 기타 문헌 자료들을 수록하였다. KAERI-SDB에는 총 31개 핵종에 대한 수착 자 료가 수록되어 있으며, 이를 Table 3에 정리하였다. KAERI$\mathrm{SDB}$ 에는 한국원자력연구원 지하연구시설(KAERI Underground Research Tunnel, KURT)을 이용하여 심부 처분환 경에서 부합하는 조건에서 측정한 핵종 수착 자료를 다수 포 함하고 있으며, 향후 꾸준히 국내 처분환경에 부합하는 수착 자료를 추가로 수록할 예정이다.

\subsection{KAERI-SDB 주요기능}

KAERI-SDB는 사용자가 시스템의 웹페이지에 접속하고 로그인을 통해 데이터베이스 서버에 접속하는 로그인 및 회원가입, 핵종 수착 자료에 대한 기본검색 및 상세검색 그 리고 검색 결과의 차트 구현 및 통계 값 표현 등의 기능들 을 포함한다.

\subsection{1 로그인 및 회원가입}

KAERI-SDB 홈페이지(http://sdb.kaeri.re.kr)에 접속하

Table 3. Elements listed in KAERI-SDB

\begin{tabular}{cl}
\hline Group & Nuclides \\
\hline Group I, II elements & Barium, cesium, radium, sodium, strontium \\
\hline Transition elements & $\begin{array}{l}\text { Cobalt, iron, manganese, molybdenum, } \\
\text { niobium, nickel, palladium, rubidium, silver, } \\
\text { technetium, yttrium, zinc, zirconium }\end{array}$ \\
\hline Lanthanides & $\begin{array}{l}\text { Cerium, europium, promethium } \\
\text { Americium, neptunium, plutonium, }\end{array}$ \\
\hline Other elements & Antimony, carbon, iodine, selenium, tin \\
\hline KAERI, Radioactive Waste Technology Development Division
\end{tabular}

Fig. 2. Main window for KAERI-SDB and member's log-in.
면 Fig. 2와 같이 사용자는 로그인을 하여 사용자 인증 후 데이터베이스를 이용할 수 있다. 처음 KAERI-SDB 웹페이 지에 들어온 사용자는 회원가입 기능을 실행하여 아이디를 생성하고 관리자의 승인 후 사용할 수 있다.

\subsection{2 자료 검색 및 저장}

기본검색 화면에서는 검색 대상 해당을 선택하고 '추가' 버튼을 누르면 Fig. 3(a)에서 보이는 것과 같이 우측의 비 어있는 창으로 선택한 핵종이 이동하고 좌측 창에서는 없 어진다. 하단에 'OR', 'AND' 체크 상자를 이용하면 선택조 건을 변경하여 데이터 검색 시 조건에 맞는 데이터를 찾 을 수 있다. 이렇게 선택한 핵종에 대한 데이터를 확인하 기 위해 '확인' 버튼을 누르면 Fig. 3(b)와 같이 Solid를 선 택하는 화면이 나타난다. 원하는 Solid 옆에 표시되어 있

(a)

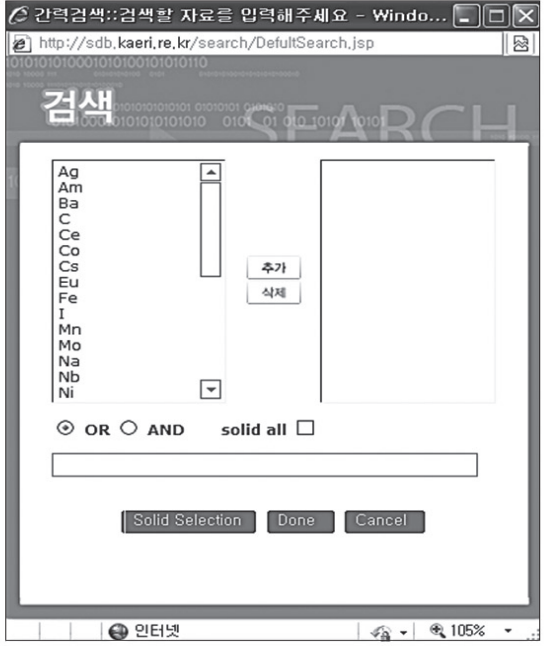

(b)

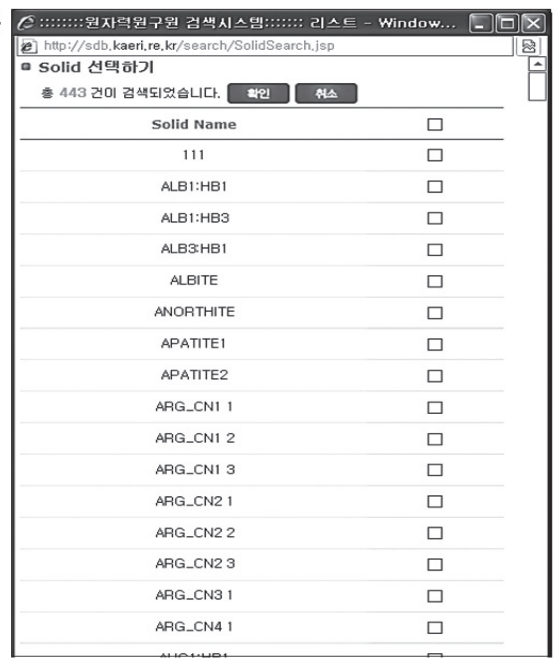

Fig. 3. Basic search for (a) selection of nuclide and (b) selection of solid. 
는 체크 상자에서 단수 또는 복수로 체크하고 '확인' 버튼 을 누르면 Fig. 4 와 같이 사용자 기본 검색 결과 화면을 확 인할 수 있다.

사용자 기본검색을 실시한 후 보다 상세한 검색을 원하면 기본검색 결과화면의 우측 상단에 있는 'Detail Search' 버튼 을 눌러 상세 검색 기능을 수행한다. 'Detail Search' 버튼을 누르면 Fig. 5 와 같은 사용자 상세 검색 입력 화면이 보이고 원하는 선택 범위를 입력 후 확인을 누르면 사용자가 원하 는 조건에서의 상세 검색 결과를 확인할 수 있다. 상세검색 에서는 사용자가 기본검색의 결과에서 특정 조건에 대한 $K_{d}$ 를 추출해 내기 위하여 $\mathrm{pH}$, 산화환원전위, 온도, 반응시간, 수용액/고체비, 이온강도, 용존유기물 및 수용액 구성 이온 농도 $\left(\mathrm{Ca}^{2+}, \mathrm{Na}^{+}, \mathrm{K}^{+}, \mathrm{Mg}^{2+}, \mathrm{F}^{-}, \mathrm{Cl}^{-}, \mathrm{NO}_{3}^{-}, \mathrm{SO}_{4}^{2-}, \mathrm{Fe}(\right.$ total $)$, $\left.\mathrm{HCO}_{3}{ }^{-}\right)$등에 대한 제한 검색을 수행하여 사용자가 원하는 특정 실험조건에서의 $K_{d}$ 를 추출할 수 있다.

기본검색 또는 상세검색 후 검색결과 창에서 각 데이터의 숫자를 선택하면 $K_{d}$ 측정을 위한 실험 조건과 수착 매질 정 보 및 참고문헌 등의 세부 내용을 확인할 수 있다. 기본검색 또는 상세검색 후 좌측상단의 'Excel download' 버튼을 누 르면 선택한 데이터를 파일 형태로 저장할 수 있다.

\subsection{3 $K_{d}$ 자료의 상세 내용 검색}

Fig. 4 에 나타낸 것처럼 기본검색 또는 상세검색의 결과 가 확인되면, 사용자는 검색결과 화면에서 “No"를 선택하 여 $K_{d}$ 측정을 위한 상세 실험내용을 확인할 수 있다. Fig. 6 에서 보여주는 것처럼 사용자는 $K_{d}$ 자료 측정에 대한 자세 한 정보를 확인함으로써 핵종 수착에 대한 지화학적 인자의 영향을 자세하게 이해할 수 있다. 상세 실험내용에는 검색 결과에 표현되는 항목 외에 산화환원 전위, 액체/고체매질 비, 실험기간 그리고, 수용액의 조성 등에 대한 내용이 포함 되어 있다. 또한, 사용자가 검색결과에 대하여 Fig. 6의 상 세 실험내용을 확인하여 특정 실험조건에 대한 $K_{d}$ 를 추출 하는 경우에 이용될 수 있다.

사용자는 Fig. 6의 실험내용이 표현된 창에서 다시 "Solid Name" 또는 "Reference Code"를 선택하여 $K_{d}$ 측정에 사용 된 고체매질에 대한 상세 정보와 참고문헌을 각각 확인할 수 있다. Fig. 7 과 8에는 고체매질 및 참고문헌에 대한 검색 창을 각각 나타내었다. "Solid Name"에서는 원소 조성, 광 물학적 조성 그리고, 물리화학적 특성 등에 대한 고체매질 의 상세 정보를 확인할 수 있으며, "Reference Code"에서는 $K_{d}$ 자료 수록 근거가 되는 참고문헌 외에 실험에 대한 추가

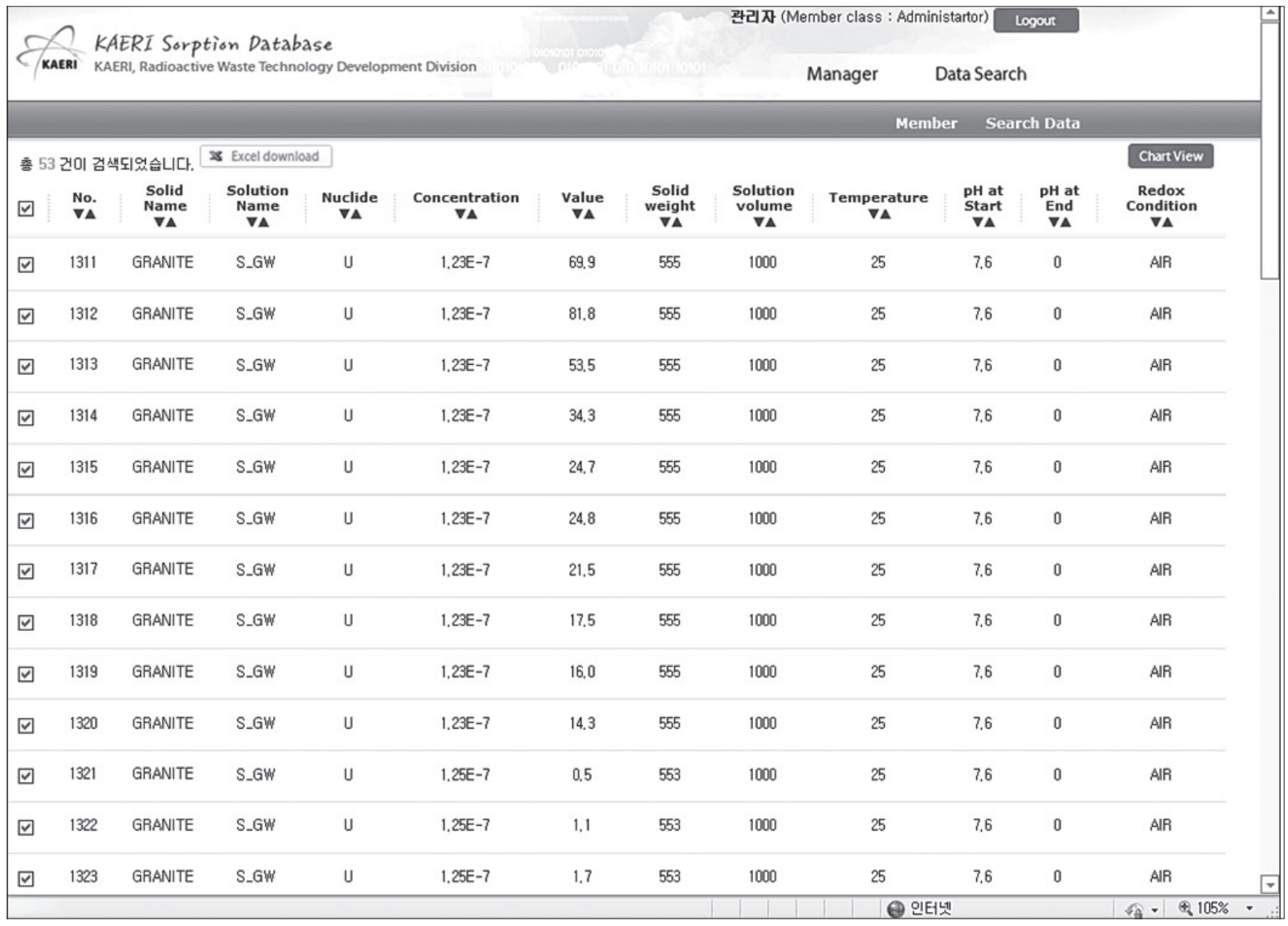

Fig. 4. Search results for strontium sorption on granite. 


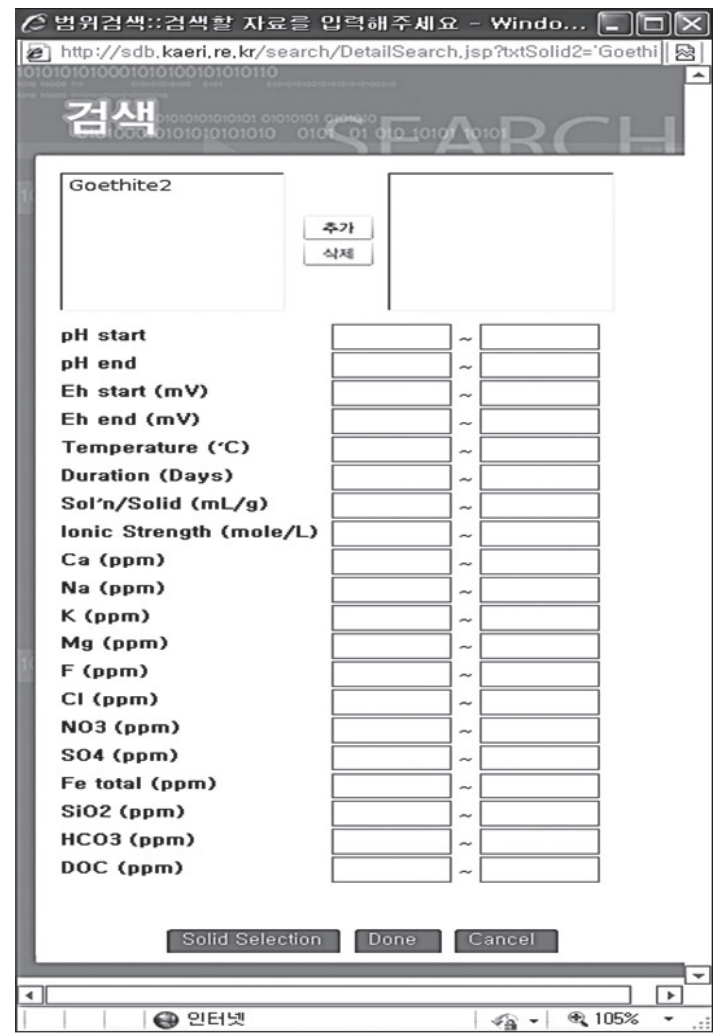

Fig. 5. Geochemical conditions for detailed search.
설명과 실험방법 등에 대한 내용이 기술되어 있다.

\subsection{4 차트 기능}

차트기능은 사용자가 검색한 자료를 그래프 형태의 결과 물로 보여주는 기능으로 KAERI-SDB에서 제공하는 차트는 산점도(scatter plot chart)와 지수도(Index chart)이다. 기 본검색 또는 상세검색을 수행한 결과가 화면에 표시되면 원 하는 데이터를 선택하고 'Chart View'를 선택하면 검색 자 료는 산점도 또는 지수도로 각각 표현된다.

산점도는 Fig. 9(a)에서 보여주듯이 사용자가 검색한 $K_{d}$ 자료 전체를 개괄적으로 보여주는 차트 기능이다. ' $\mathrm{X}$ 축 설 정하기' 기능을 이용하여 $\mathrm{pH}$, 산화환원전위, 이온강도, 탄 산염, 용존 유기탄소, 핵종 농도, 수용액/광물 비 그리고, 반 응시간 등의 다양한 지화학적 조건에 대한 개괄적인 $K_{d}$ 분 포를 도식화하여 확인할 수 있다. 이는 사용자가 핵종 수착 에 영향을 주는 주요 요소에 대한 결과를 X축에 정의함으로 써 전체범위에 대해서 수착경향을 확인할 수 있게 해 준다. 또한, $K_{d}$ 분포는 실험조건에 따라서 수십 배에서 수천 배 이 상 차이가 나는 경우가 있으므로 지화학적 조건에 따라서 큰 폭의 $K_{d}$ 분포를 나타내는 특성을 고려하여 Y축을 일반 스케일과 로그 스케일로 표현이 가능하도록 구성하였다.

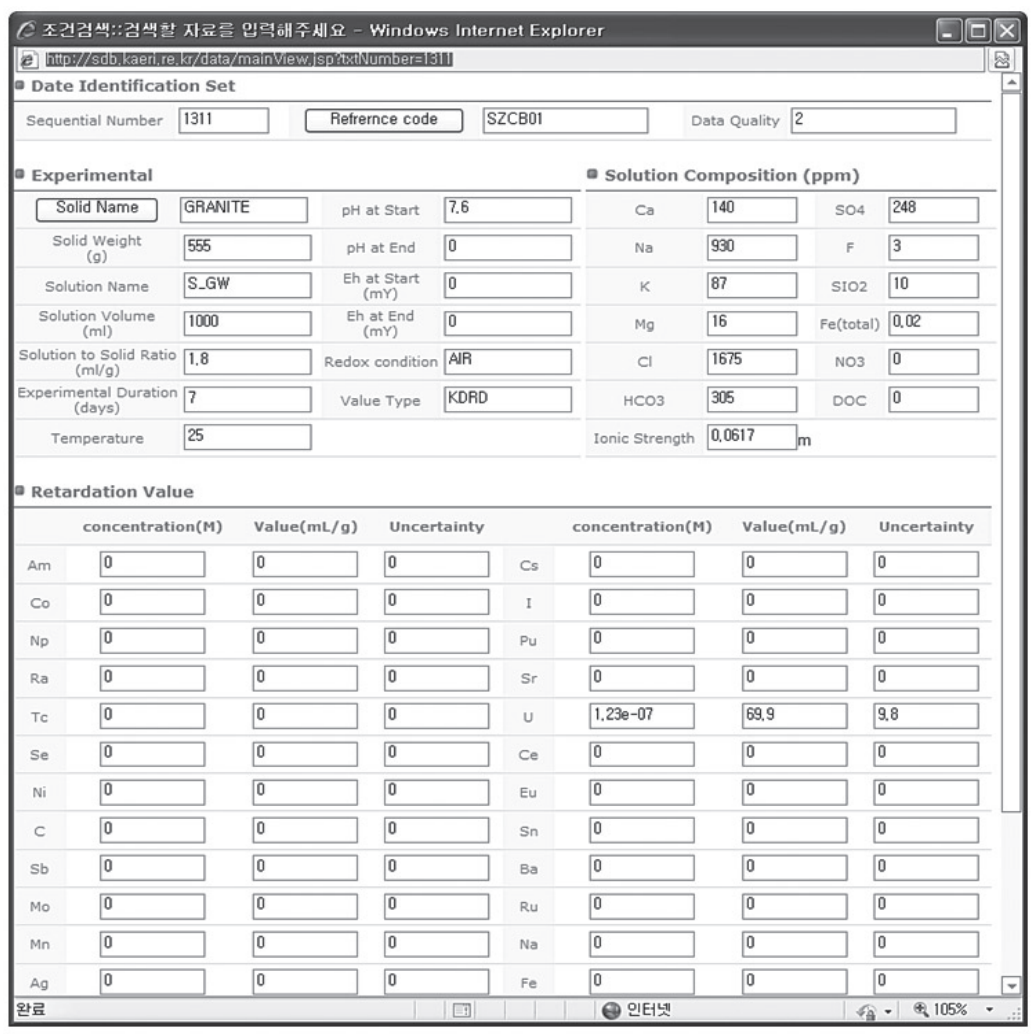

Fig. 6. Detailed experimental conditions for the measurement of $K_{d}$. 


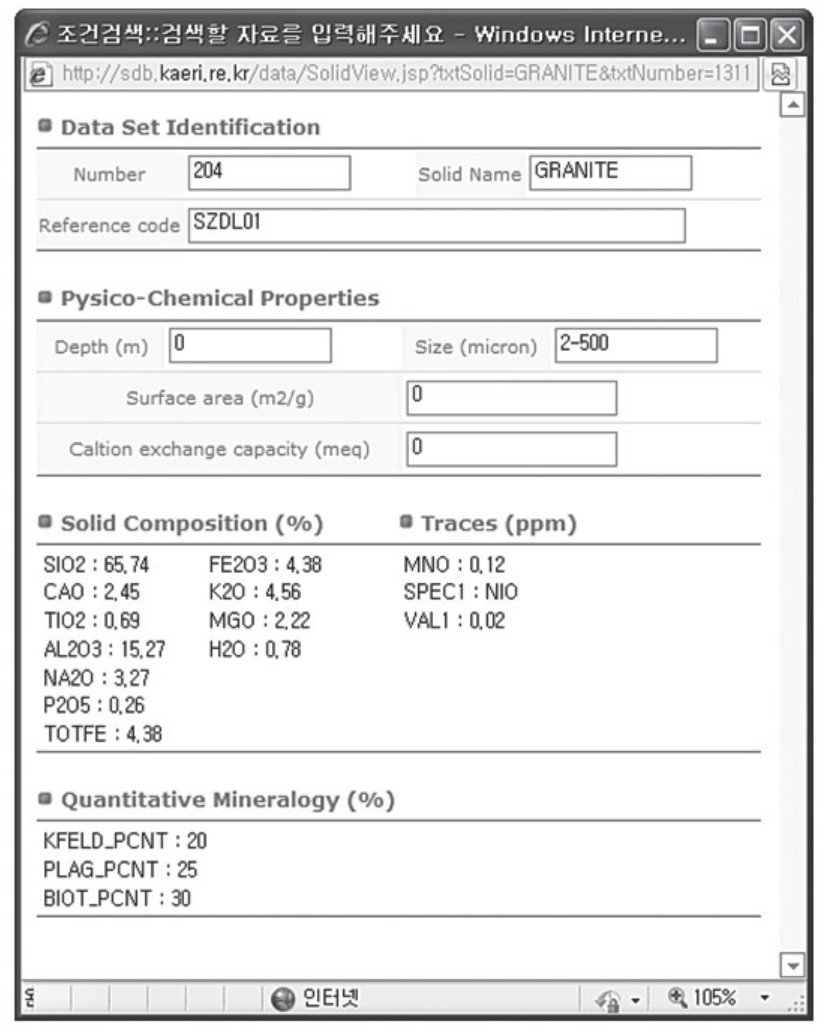

Fig. 7. Detailed information on the solid used in the measurement of $K_{d}$.

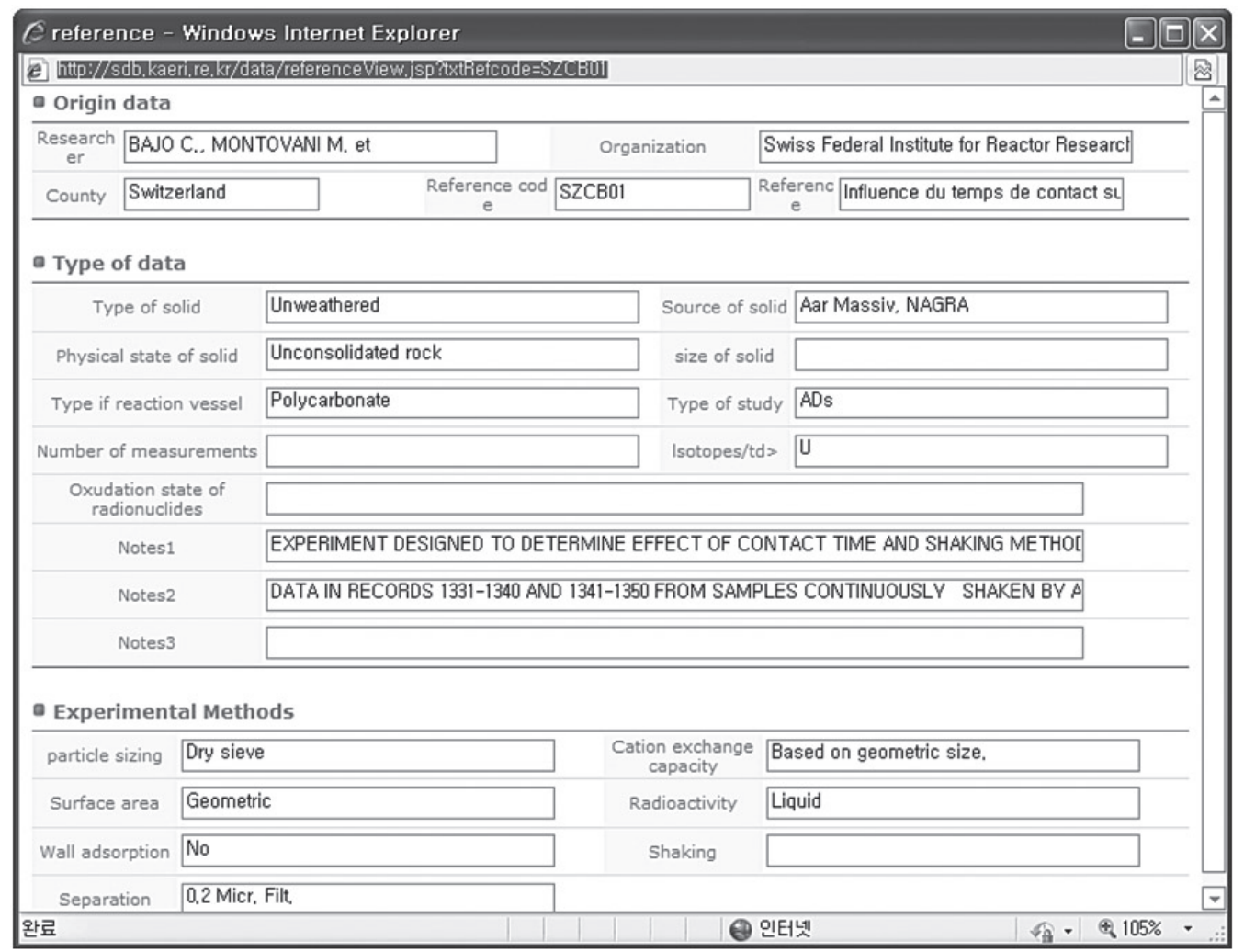

Fig. 8.Detailed information on the reference and experimental methods. 


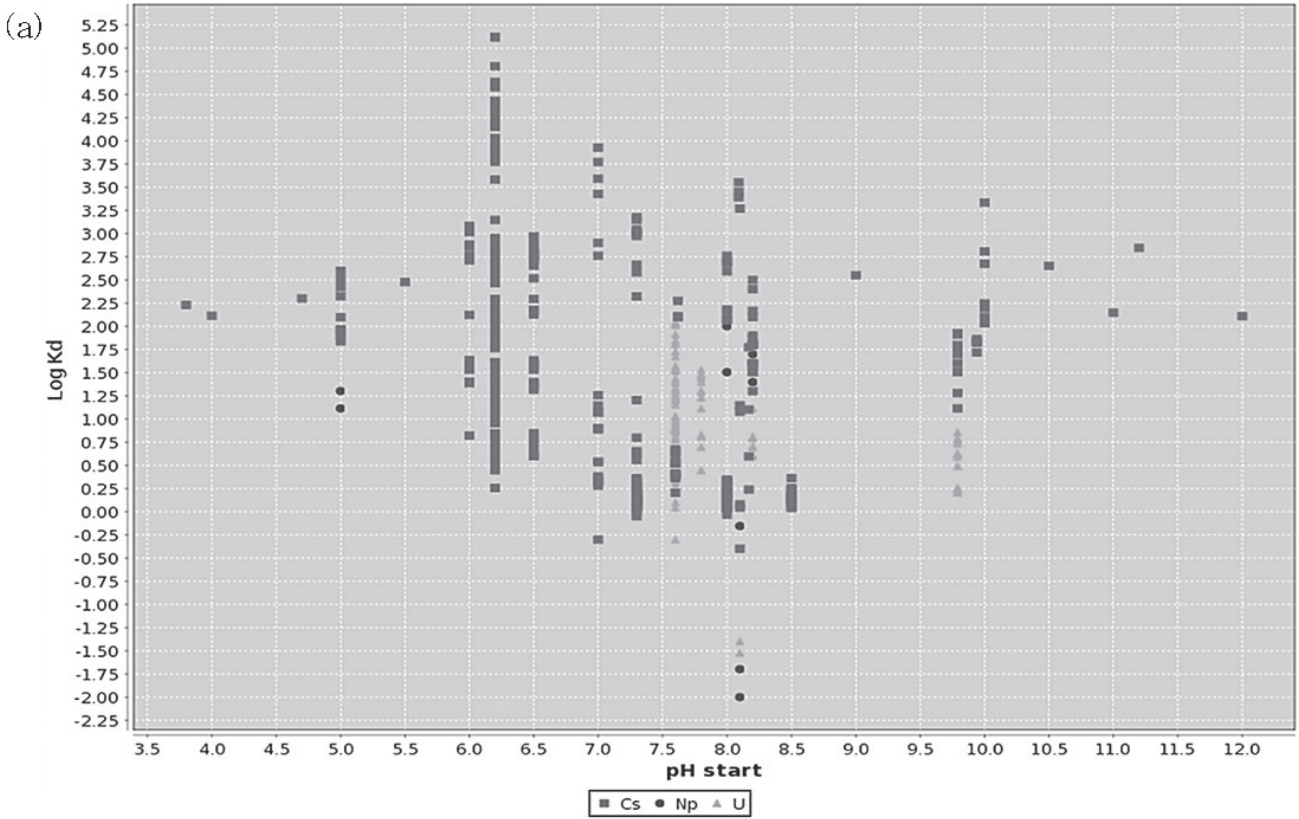

(b)

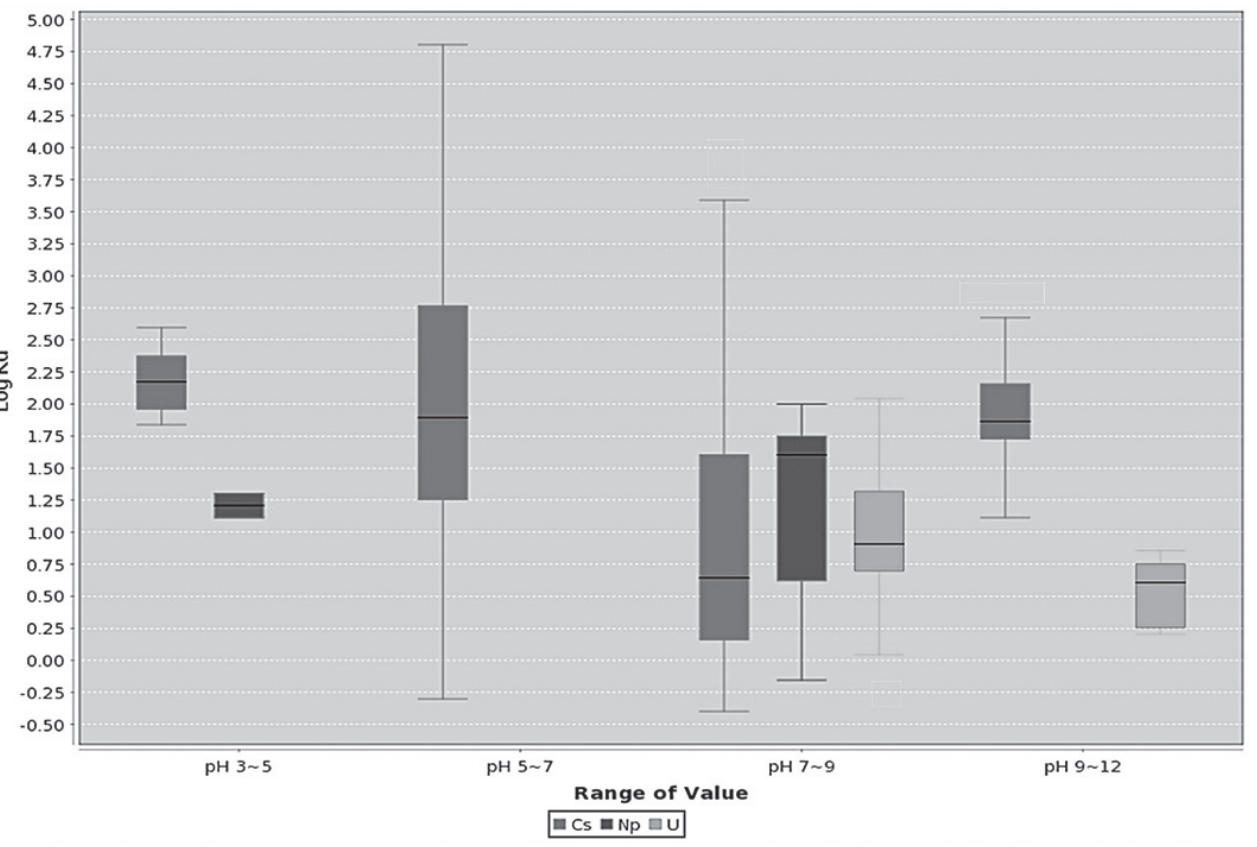

- 구간별 모평균 $95 \%$ 신뢰구간

\begin{tabular}{cccc}
\hline & Cs & Np & U \\
\hline PH 3 5 & $2.1868 \pm 0.1294$ & $1.2075 \pm 0.5906$ & \\
\hline PH 5 7 & $2.0355 \pm 0.1183$ & & \\
\hline PH 7 9 & $0.9957 \pm 0.1077$ & $0.8772 \pm 0.8017$ & $0.9464 \pm 0.124$ \\
\hline PH 9 12 & $1.9959 \pm 0.1436$ & & $0.5364 \pm 0.1256$ \\
\hline
\end{tabular}

Fig. 9. Search results of sorption of cesium, neptunium, and uranium by granitic rock expressed by (a) scatter plot chart and (b) index chart. 
지수도는 $K_{d}$ 분포에 영향을 주는 주요 지화학적 영향인 자를 일정 구간별로 표현하는 경우에 사용할 수 있다. 핵 종의 수착 특성은 지화학적 조건에 매우 민감하게 변화하 므로 수착에 중요한 영향을 미치는 주요 지화학적 조건에 대하여 범주별로 2 4 수준으로 범위를 설정하여 지수도를 구현할 수 있다. 지수도에서 표현되는 지화학적 조건들은 $\mathrm{pH}$, 산화환원전위, 이온강도, 탄산염 그리고, 용존 유기물 등이다. 지수도에 표현되는 각각의 지화학적 변수와 변수 들의 범주 및 수준별 범위를 Table 4에 정리하였다. 지수도 표현을 위하여 산점도 화면 상단의 'Index Chart' 항목에서 $\mathrm{pH}$, Eh, Ionic Strength(IS), Dissolved Carbonate $\left(\mathrm{CO}_{3}{ }^{2-} /\right.$ $\mathrm{HCO}_{3}^{-}$) 그리고 Dissolved Organic Carbon(DOC) 중 하나 를 선택하면 Fig. 9(b)와 같이 해당 지화학적 조건의 범주 별 지수도로 나타낼 수 있다. 지수도에서는 산점도와 마찬 가지로 화면상의 Y축을 일반 또는 로그 스케일로 설정하여

Table 4. Indices of geochemical parameters and their ranges applied to index chart

\begin{tabular}{|c|c|c|}
\hline Geochemical parameters & Levels of indices & Ranges \\
\hline \multirow{4}{*}{$\mathrm{pH}$} & Strong acidic & $3 \sim 5$ \\
\hline & Weak acidic & $5 \sim 7$ \\
\hline & Weak alkaline & $7 \sim 9$ \\
\hline & Strong alkaline & $9 \sim 12$ \\
\hline \multirow{4}{*}{$\begin{array}{l}\text { Eh } \\
(\mathrm{mV})\end{array}$} & Strong reducing & $-400 \sim-150$ \\
\hline & Weak reducing & $-150 \sim 0$ \\
\hline & Weak oxidizing & $0 \sim 150$ \\
\hline & Strong oxidizing & $150 \sim 400$ \\
\hline \multirow{4}{*}{$\begin{array}{l}\text { Ionic strength } \\
(\mathrm{mol} / \mathrm{L})\end{array}$} & Very low & $10^{-4} \sim 10^{-3}$ \\
\hline & Low & $10^{-3} \sim 10^{-2}$ \\
\hline & High & $10^{-2} \sim 10^{-1}$ \\
\hline & Very high & $10^{-1} \sim 1$ \\
\hline \multirow{4}{*}{$\begin{array}{c}\text { Dissolved carbonate } \\
\left(\mathrm{CO}_{3}^{2-} \text { and } / \text { or } \mathrm{HCO}_{3}{ }^{-}\right) \\
(\mathrm{mg} / \mathrm{L})\end{array}$} & Very low & $0.6 \sim 60$ \\
\hline & Low & $60 \sim 300$ \\
\hline & Medium & $300 \sim 600$ \\
\hline & High & $600 \sim 3000$ \\
\hline \multirow{2}{*}{$\begin{array}{l}\text { Dissolved organic carbon } \\
\text { (DOC) }(\mathrm{mg} / \mathrm{L})\end{array}$} & Low DOC & $10^{-3} \sim 10^{-1}$ \\
\hline & High DOC & $10^{-1} \sim 10$ \\
\hline
\end{tabular}

결과를 확인할 수 있다. 또한 지수도에는 통계기능을 추가 하여 지수도 하단부에 ‘구간별 모평균 95\% 신뢰구간' 테이 블을 표시하여 검색 결과에 대한 신뢰도를 확인할 수 있도 록 구현하였다. 표본 크기가 $\mathrm{n} \geqq 30$ 일 때는 모집단이 어떤 분포를 따르더라도 좋은 결과를 기대할 수 있다[22].

\subsection{5 관리자 기능}

KAERI-SDB는 웹브라우저를 이용하여 사용자가 $K_{d}$ 자료 를 열람하므로 관리자가 사용자, 수착 자료 그리고, 검색정 보 등을 관리할 수 있다. 사용자는 일반 사용자와 관리자로 구분하여 기능별 접근권한을 부여하도록 되어 있다. 수착 자료 관리 기능은 관리자가 자료를 신규 등록하거나 수정 하는 기능으로 Fig. $6 \sim 8$ 에 기술된 상세 실험내용, 고체매 질 그리고 참고문헌 등에 대한 자료를 등록 및 수정할 수 있 다. 자료 관리 기능은 일반 사용자들이 검색을 보다 손쉽게 할 수 있도록 도와주는 기능으로 검색 제목, 검색 내용 설 명, 검색 조건 입력, 검색 범위 지정의 항목을 입력할 수 있 도록 설계되고 구현되었다.

\subsection{KAERI-SDB 응용}

$\mathrm{KAERI-SDB}$ 를 이용하여 $K_{d}$ 를 검색하고 추출하여 지화학 조건의 변화에 따른 핵종의 수착특성을 평가하기 위한 사례 연구를 수행하였다. 각 사례별 검색 및 추출 조건을 Table 5에 요약하였다.

\subsection{1 광물에 따른 우라늄의 수착 특성 비교}

심부 지하 처분환경에서 핵종은 지하수 흐름을 따라 암반 의 균열을 통해 이동할 것이다. 이 때 암반 균열에 존재하는 충전광물들은 핵종과 반응하여 핵종의 이동에 영향을 미친 다. 본 사례에서는 KAERI-SDB를 이용하여 광물에 따른 핵 종의 수착 특성을 비교하였다. 검색의 범위는 핵종으로 우

Table 5. Experimental conditions of the case studies using KAERI-SDB

\begin{tabular}{|c|c|c|c|c|c|c|c|}
\hline \multirow{3}{*}{$\begin{array}{c}\text { Radionuclide } \\
\text { Concentration of } \\
\text { radionuclide }(\mathrm{mol} / \mathrm{L})\end{array}$} & \multirow{2}{*}{\multicolumn{4}{|c|}{$\begin{array}{c}\text { Case I } \\
\text { Uranium }\end{array}$}} & \multicolumn{2}{|c|}{ Case II } & \multirow{3}{*}{$\begin{array}{c}\text { Case III } \\
\text { Uranium } \\
10^{-6}-10^{-4}\end{array}$} \\
\hline & & & & & \multirow{2}{*}{$\begin{array}{l}\text { Cesium } \\
10^{-9}-10^{-5}\end{array}$} & \multirow{2}{*}{$\frac{\text { Strontium }}{10^{-9}-10^{-5}}$} & \\
\hline & $10^{-7}-10^{-5}$ & $\sim 10^{-4}$ & $10^{-6}-10^{-4}$ & $10^{-6}$ & & & \\
\hline Solid & Granite & Chlorite & Kaolinite & Hematite & Granite & Granite & Kaolinite \\
\hline $\begin{array}{l}\text { Ratio of solution to } \\
\text { solid }(\mathrm{mL} / \mathrm{g})\end{array}$ & $1.8-10$ & $\sim 80$ & $\sim 80$ & $\sim 1200$ & $10-200$ & $10-200$ & 100 \\
\hline Redox condition & Aerobic & Aerobic & Aerobic & Aerobic & Aerobic & Aerobic & Aerobic \\
\hline
\end{tabular}


라늄 그리고 고체매질로는 방사성폐기물 처분장 모암의 후 보 물질인 화강암과 화강암의 균열에 충전광물로 존재할 수 있는 녹니석, 카올리나이트, 적철석에 대한 우라늄의 $K_{d}$ 를 검색하고 추출하였다. Table 6에는 각 광물별로 우라늄의 수착 검색 결과에 대한 $\mathrm{pH}$ 구간별 $95 \%$ 신뢰도 구간에서 우 라늄의 $K_{d}$ 평균값을 나타내었다.

KAERI-SDB를 이용한 검색 결과, 4 가지 광물에 대한 우라 늄의 수착 친화도는 화강암 〈 녹니석 〈카올리나이트<적 철석 순으로 나타났으며, 검색대상의 모든 광물들에 대하 여 공통적으로 $\mathrm{pH}$ 에 의존적인 수착경향을 보여준다. 적철 석의 경우를 제외하고 우라늄은 $\mathrm{pH} 3 \sim 5$ 에서 거의 수착이 되지 않거나 적게 수착이 되는 것을 확인할 수 있다. $\mathrm{pH} 5$ $\sim 7$ 사이에 우라늄 수착이 급격히 증가하였으며 알칼리 영 역으로 $\mathrm{pH}$ 가 증가하면서 다시 감소하는 것을 확인할 수 있 다. 이는 산화상태에서 우라늄은 우라늄(VI)의 형태로 존 재하며 용존 탄산염과 반응하여 우라닐-탄산 이온을 형성 하기 때문에 알칼리 영역에서 $K_{d}$ 가 감소하는 것으로 이해 할 수 있다[23].

화강암의 우라늄에 대한 $K_{d}$ 는 $\mathrm{pH}$ 에 따라 $3.6 \pm 0.4 \sim 33.7$ $\pm 8.9 \mathrm{~mL} / \mathrm{g}$ 의 범위로 분포하였다. $K_{d}$ 값은 산 영역에서 부터 $\mathrm{pH}$ 가 증가함에 따라 점차 증가하다가 $\mathrm{pH} 5 \sim 7$ 영 역에서 최고값을 가진 후 감소하는 경향을 나타내고 있다. 한편 녹니석에 대한 우라늄의 $K_{d}$ 는 $11.4 \pm 5.1 \sim 492.8$ $\pm 243.7 \mathrm{~mL} / \mathrm{g}$ 의 범위로 분포하였으며, $\mathrm{pH} 5 \sim 9$ 의 범위 에서 화강암에 대한 우라늄의 $K_{d}$ 보다 10 배 정도 큰 것으 로 확인되었다. 녹니석은 암반의 단열 충전광물로 존재하 거나 화강암과 같은 암석에 미량 함유되어 있다. 특히 화 강암과 같은 암석에 녹니석이 미량 함유되어 있을 경우, 우 라늄의 수착에 대한 기여도가 큰 광물로 알려졌다[24]. 이 는 녹니석에 철 성분이 함유되어 있기 때문에 이들 철 성분 이 용출되어 철산화물을 형성하여 수착을 증가시키는 것 으로 이해할 수 있다[25]. 카올리나이트에 대한 우라늄의 $K_{d}$ 는 $9.8 \pm 2.8 \sim 604.6 \pm 246.1 \mathrm{~mL} / \mathrm{g}$ 의 범위로 녹니석 보다 높은 것으로 확인되었다. 카올리나이트는 녹니석이

Table 6. The population mean of $K_{d}$ values of uranium sorption by different geological media as a function of $\mathrm{pH}$ at $95 \%$ of confidence interval

\begin{tabular}{ccccc}
\hline \multirow{2}{*}{$\mathrm{pH}$} & \multicolumn{4}{c}{$K d(\mathrm{~mL} / \mathrm{g})$} \\
\cline { 2 - 5 } & Granite & Chlorite & Kaolinite & Hematite \\
\hline $3-5$ & $7.5 \pm 2.1$ & $11.4 \pm 5.1$ & $9.8 \pm 2.8$ & $424.9 \pm 214.2$ \\
\hline $5-7$ & $33.7 \pm 8.9$ & $492.8 \pm 243.7$ & $604.6 \pm 246.1$ & $8440.1 \pm 2722.0$ \\
\hline $7-9$ & $24.2 \pm 12.3$ & $234.0 \pm 76.1$ & $553.5 \pm 171.2$ & $815.2 \pm 408.1$ \\
\hline $9-12$ & $3.6 \pm 0.4$ & N/A & $82.8 \pm 111.4$ & N/A \\
\hline
\end{tabular}

풍화되어 형성되며[26], 최근에는 이온교환을 주로 하는 다 른 점토광물과는 달리 표면 착물형성을 통하여 핵종을 수 착하며 카올리나이트에 함유되어 있는 예추석 등에 의하여 다른 점토광물들 보다 우라늄에 대한 수착 친화도가 더 높 은 것으로 보고되고 있다[27]. 적철석에 대한 우라늄의 $K_{d}$ 는 $424.9 \pm 214.2 \sim 8440.1 \pm 2722.0 \mathrm{~mL} / \mathrm{g}$ 의 범위로 분포 하여 사례연구에 포함된 다른 광물들의 $K_{d}$ 보다 가장 높게 분포하는 것으로 확인되었다. 침철석과 같은 산화철 광물 은 주로 단열 충전광물로 존재하며 악틴족 원소나 일부 금 속이온에 대한 수착친화도가 크기 때문에 $K_{d}$ 가 높은 것으 로 평가된다[28].

\section{4 .2 세슘과 스트론튬 수착에 미치는 이온강도의 영향}

핵종을 세슘 또는 스트론튬으로 선택하고, 화강암을 수착 매질로 선정하여 이들 핵종의 수착에 미치는 이온강도의 영 향을 평가하였다. 지수도를 이용하여 검색결과를 이온강도 범주에 따른 $K_{d}$ 분포로 표현하였다. Fig. 10에 나타내었듯 이 세슘과 스트론튬은 이온강도에 민감하게 반응하는 것으 로 나타났다. 이온강도가 $0.0001 \sim 0.001 \mathrm{~mol} / \mathrm{L}$ 의 범위에 서 $0.1 \sim 1 \mathrm{~mol} / \mathrm{L}$ 로 증가할 때, 세슘의 $K_{d}$ 평균값은 $446.7 \pm$ $95.1 \mathrm{~mL} / \mathrm{g}$ 에서 $11.6 \pm 2.4 \mathrm{~mL} / \mathrm{g}$ 으로 감소하였으며, 스트론 튬은 $124.9 \pm 78.1 \mathrm{~mL} / \mathrm{g}$ 에서 $1.8 \pm 0.4 \mathrm{~mL} / \mathrm{g}$ 으로 감소하였 다. 이는 세슘과 스트론튬이 화강암에 포함된 규산염광물의 고정된 전하점에서 이온 교환에 의해 수착되기 때문에 이온 강도가 증가할수록 용액 중에 세슘 및 스트론튬과 경쟁관계 에 있는 $\mathrm{Na}^{+}, \mathrm{K}^{+}, \mathrm{Ca}^{2+}$ 그리고, $\mathrm{Mg}^{2+}$ 등의 이온이 증가하여 이들의 $K_{d}$ 가 감소하는 것으로 판단된다[29].

\subsection{3 카올리나이트의 우라늄 수착에 대한 탄산염 의 영향}

우라늄 수착에 대한 탄산염의 영향을 평가하기 위하여 기 본검색 및 상세검색을 수행하였다. 핵종을 우라늄, 고체매 질을 카올리나이트로 각각 설정하여 기본검색을 수행하였 다. 기본검색 결과 중에서 원하는 자료를 얻기 위하여 온도 및 탄산염 농도를 설정하여 상세검색을 수행하였다. Fig. 11 에는 카올리나이트의 우라늄 수착에 대한 탄산염의 영향을 나타내었다. 상세검색 결과를 통하여 카올리나이트의 우라 늄 수착은 탄산염에 많은 영향을 받는 것을 알 수 있다. 이 는 산화상태에서 탄산염이 우라늄 화학종 형성에 영향을 주 기 때문인 것으로 생각된다[23]. 우라늄의 화학종 형성에 대 한 탄산염의 영향을 이해하기 위하여 OECD/NEA 열역학자 료[30]를 이용하여 Visual MINTEQ[31]로 계산하여 이용하여 총 우라늄 농도가 $10^{-6} \mathrm{~mol} / \mathrm{L}$ 이고, 이온강도가 $0.01 \mathrm{~mol} / \mathrm{L}$ 


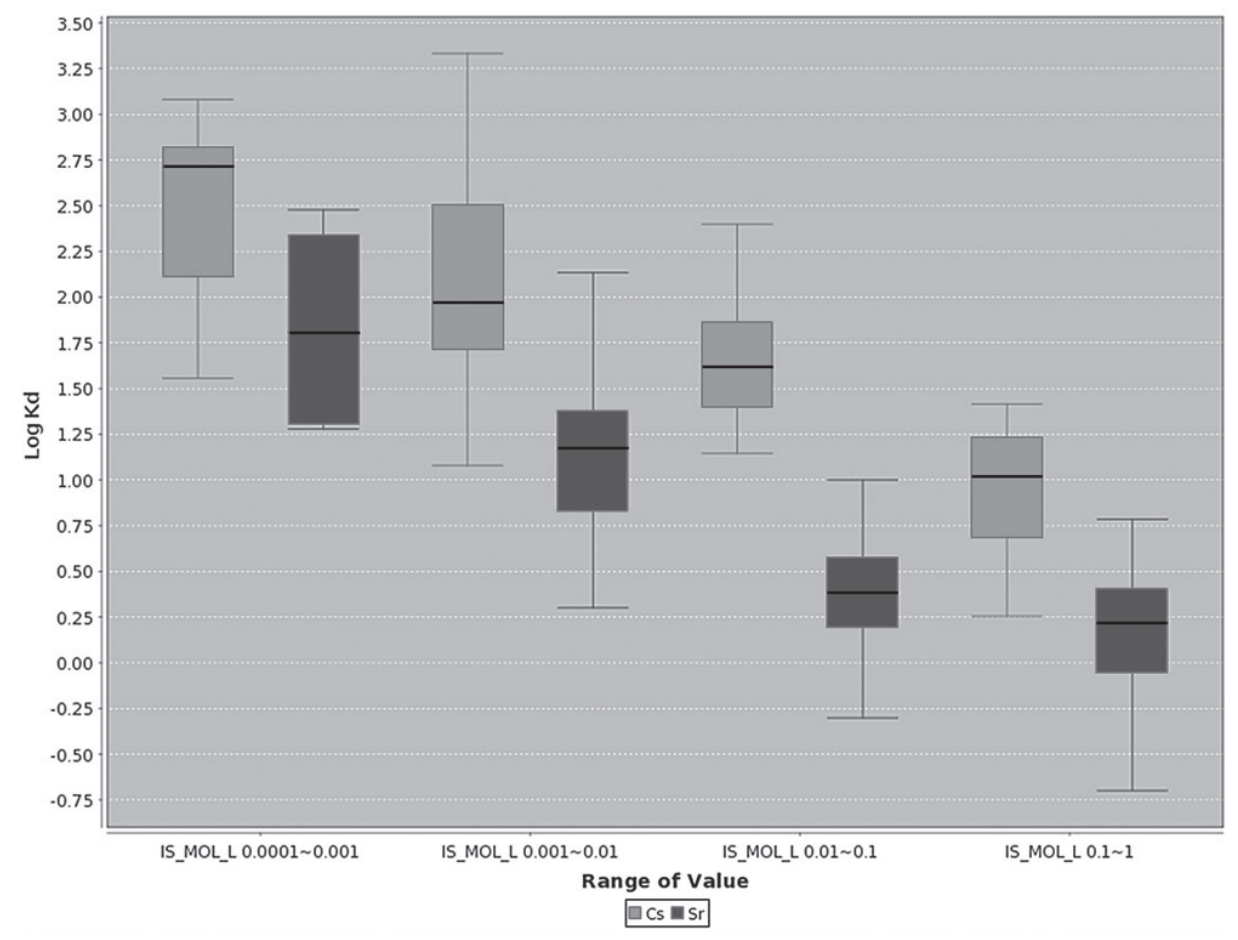

Fig. 10. Effect of ionic strength on the sorption of cesium and strontium by granite.

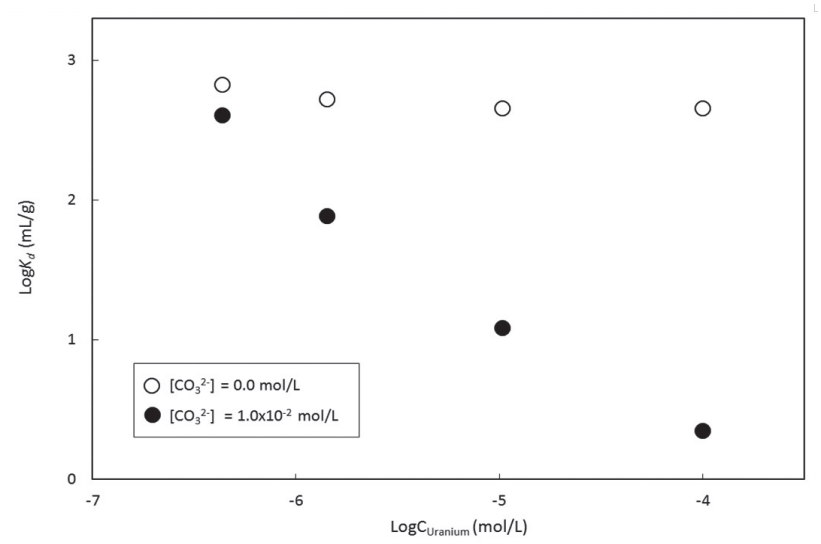

Fig. 11. Effect of carbonate on the sorption of uranium by kaolinite as a function of uranium concentration.

일 때, 탄산염이 있는 경우와 없는 경우에 대한 $\mathrm{pH}$ 변화에 따른 우라늄 화학종의 분포를 각각 구하였다. Fig. 12에서 보 여주듯이 탄산염이 없을 때, 우라늄은 주로 $\mathrm{UO}_{2}^{2+}, \mathrm{UO}_{2} \mathrm{OH}^{+}$, $\left(\mathrm{UO}_{2}\right)_{3}(\mathrm{OH})_{5}{ }^{+}$그리고 $\mathrm{UO}_{2}(\mathrm{OH})_{3}{ }^{-}$등의 우라닐 또는 수산화우 라닐 이온의 형태로 분포한다. 그러나 우라늄은 탄산염과의 반응성이 매우 강하기 때문에 탄산염이 $0.01 \mathrm{~mole} / \mathrm{L}$ 로 존재 할 때, $\mathrm{pH} 5$ 이상의 영역에서 $\mathrm{UO}_{2} \mathrm{CO}_{3}(\mathrm{aq}), \mathrm{UO}_{2}\left(\mathrm{CO}_{3}\right)_{2}{ }^{2-}$ 그 리고 $\mathrm{UO}_{2}\left(\mathrm{CO}_{3}\right)_{3}^{4}$ 등의 우라닐-탄산 이온의 형태로 주로 분 포한다(Fig. 13). 따라서 카올리나이트의 우라늄 수착에 대 한 상세검색 결과와 화학종 계산결과는 수용액 중의 탄산염

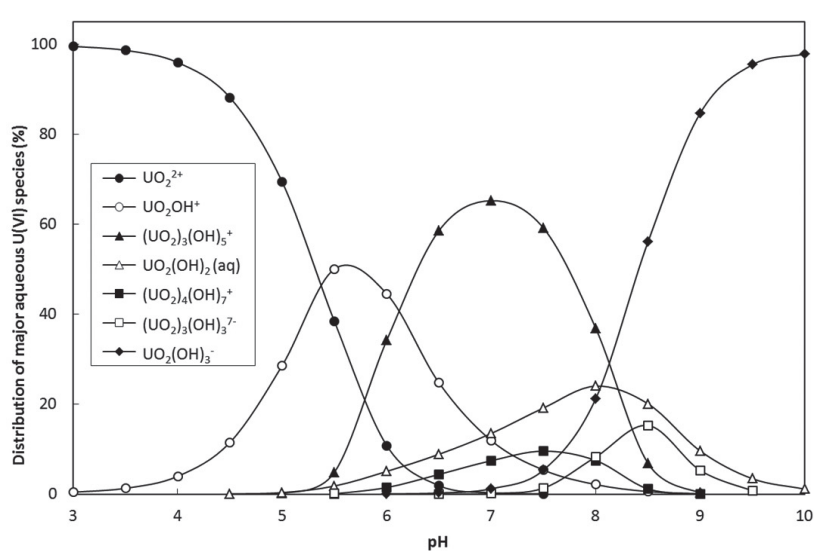

Fig. 12. Distribution of major aqueous uranium(VI) species at [Uranium(VI)] $=10^{-6} \mathrm{~mol} / \mathrm{L},\left[\mathrm{CO}_{3}{ }^{2-}\right]=0 \mathrm{~mol} / \mathrm{L}$, and $\mathrm{I}=10^{-2} \mathrm{~mol} / \mathrm{L}$.

이 우라늄 수착에 영향을 주어 처분환경에서 우라늄의 이동 에 중요한 역할을 함을 시사한다.

\section{4. 결 론}

기존에 개발된 핵종 수착 데이터베이스 프로그램인 SDB$21 \mathrm{C}$ 를 분석하고 사용자의 요구사항을 반영하여 사용자가 쉽게 접근할 수 있는 웹기반 핵종 수착 데이터베이스인 KA$\mathrm{ERI}-\mathrm{SDB}$ 를 개발하였다. KAERI-SDB는 로그인/회원가입, $K_{d}$ 자료 검색, 추출 및 저장, 차트구현 그리고 검색된 자료의 통 


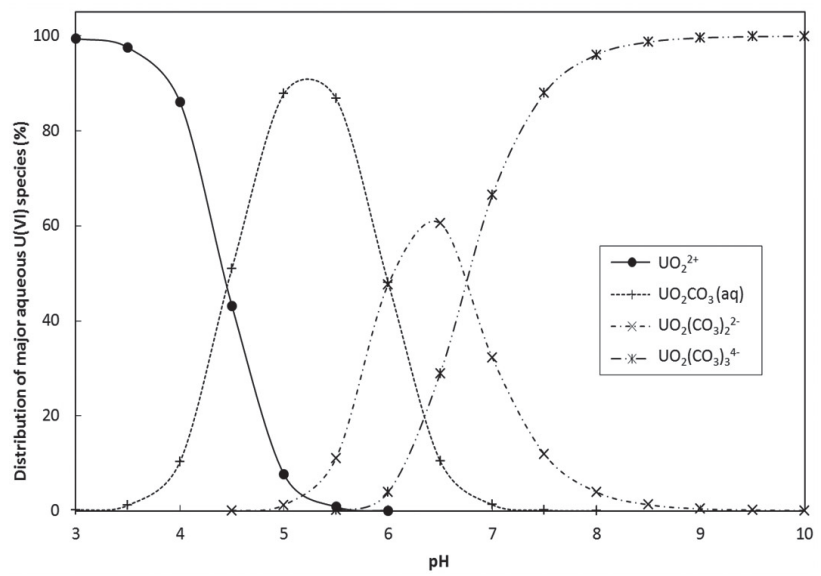

Fig. 13. Distribution of major aqueous uranium(VI) species at [Uranium(VI)] $=10^{-6} \mathrm{~mol} / \mathrm{L},\left[\mathrm{CO}_{3}{ }^{2-}\right]=0.01 \mathrm{~mol} / \mathrm{L}$, and I $=10^{-2} \mathrm{~mol} / \mathrm{L}$.

계처리 등의 다양한 기능을 포함하도록 고안되었다. KAERI$\mathrm{SDB}$ 는 기본검색을 통하여 특정 광물들에 대한 특정 핵종들 의 $K_{d}$ 값들을 추출할 수 있으며, 상세검색을 통하여 기본 검 색된 자료들을 다양한 지화학적 조건별로 추출할 수 있다. 또한 검색 및 추출한 자료를 저장하거나 산점도 또는 지수 도 등으로 표현할 수 있다. KAERI-SDB의 특징들을 다음과 같이 요약할 수 있다.

· 특정 지화학적 조건에서 단일 $K_{d}$ 값 및 분포 추출

· 산점도를 이용한 지화학적 조건 변화에 따른 핵종의 수 착경향 평가

· 지수도를 이용한 특정 지화학적 조건의 범위 내에서 핵 종의 수착 자료 평가

· 통계적 방법을 이용한 핵종 수착 자료 평가

KAERI-SDB의 핵종 수착 자료는 OECD/NEA 및 국내 생 산 자료를 포함하고 있으며, 향후 지속적으로 국내외의 핵 종 수착 자료를 보완해 나갈 예정이다. 웹을 기반으로 운용 되는 KAERI-SDB의 보급을 통하여 핵종 수착 관련 자료에 대한 일반인의 접근성을 증대시킴으로써 방사성폐기물 처 분에 대한 신뢰성을 증진시킬 수 있을 것으로 기대된다. 특 히, KAERI-SDB는 방사성폐기물 처분장의 성능평가와 규 제관련 업무 종사자들에게 처분안전성 평가에 필요한 수착 자료를 편리한 방법으로 제공할 뿐만 아니라, 계면반응 관 련 연구분야에도 유용한 정보를 제공할 수 있을 것이다. 아 울러, 국제 사회에 국내의 핵종 수착데이터베이스 관리체 계와 현황에 대한 근거자료를 제시하여 방사성폐기물 처분 안전성 평가에 대한 대외적인 신뢰도 확보에 기여할 수 있 을 것이다.

\section{감사의 글}

본 논문은 교육과학기술부에서 시행하는 원자력연구개 발사업의 일환으로 한국연구재단의 지원을 받아 수행되었 습니다.

\section{REFERENCES}

[1] N.A. Chapman, I.G. McKinnley and M.D. Hill, The Geological Disposal of Nuclear Waste, John Wiley \& Sons, Inc., Chichester (1987).

[2] I. Casas, D. Casabona, L. Duro and J. Pablo, "The Influence of Hematite on the Sorption of Uranium(VI) onto Granite Filling Fractures", Chem. Geol., 113, pp. 319-326 (1994).

[3] J.P. McKinley, J.M. Zachara, S.C. Smith and G.D. Turner, "The Influence of Uranyl Hydrolysis and Multiple Site-binding Reactions on Adsorption of U(VI) to Montmorillonite", Clay. Clay Miner., 43, pp. 586-598 (1995).

[4] M.H. Baik and W.J. Cho, "An Experimental Study on the Sorption of Uranium(VI) onto a Bentonite Colloid", J. of the Korean Radioactive Waste Society, 4(3), pp. 235-243 (2006).

[5] M.H. Baik, J.K. Lee, S.Y. Lee and S.S. Kim, "Sorption of Eu(III) and Th(IV) on Bentonite Colloids Considering Their Precipitation and Colloid Formation", J. of the Korean Radioactive Waste Society, 6(2), pp. 129-139 (2008).

[6] I.G. Mckinley and A. Scholtis, "Compilation and Comparison of Radionuclide Sorption Database used in Recent Performance Assessments", Proc. of an NEA Workshop on Radionuclide Sorption from the Safety Evaluation Perspective, Interlaken, Switzerland (1991).

[7] D.B. Kent, V.S. Tripathi, N.B. Ball and J.O. Leckie, Surface-Complexation Modeling of Radionuclide Adsorption in Sub-Surface Environments, Stanford Civil Engineering Tech. Rept. \#294, Stanford, CA / NUREG Rept. CR-4897, SAND 86-7175 (1988).

[8] B. Ruegger and K. Ticknor, "The NEA Sorption Data Base (SDB)" In: NEA Workshop on Radionuclide 
Sorption from the Safety Evaluation Perspective, Interlaken, October 16-18 (1991).

[9] V. Brendler, A. Vahle, T. Arnold, G. Bernhard and T. Fanghänel, "RES3T-Rossendorf Expert System for Surface and Sorption Thermodynamics", J. Contamin. Hydr. 61, pp. 281-291 (2003).

[10] http://migrationdb.jaea.go.jp/english.html.

[11] S. Goldberg, "Use of Surface Complexation Models in Soil Chemical Systems", Adv. Agron., 47, pp. 233329 (1992).

[12] W. Stumm, H. Hohl and F. Dalang, "Interaction of Metal Ions with Hydrous Oxide Surfaces", Croat. Chem. Acta, 48, pp. 491-504 (1976).

[13] W. Stumm, C.P. Huang and S.R. Jenkins, "Specific Chemical Interaction affecting the Stability of Dispersed Systems", Croat. Chem. Acta, 42, pp. 223-245 (1970).

[14] H. Hohl and W. Stumm, "Interaction of $\mathrm{Pb} 2+$ with Hydrous $\gamma-\mathrm{Al}_{2} \mathrm{O}_{3}$ ", J. Coll. Interf. Sci., 55, pp. 281288 (1976).

[15] D.E. Yates, S. Levine and T.W. Healy, "Site-binding Model of the Electrical Double Layer at the Oxide/ Water Interface", J. Chem. Soc. Faraday Transactions, 70, pp. 1807-1818 (1974).

[16] J.C. Westall and H. Hohl, "A comparison of electrostatic models for the oxide/solution interface", Adv. Colloid Interfac., 12, pp. 265-294 (1980).

[17] G.H. Bolt and W.H. van Riemsdijk, Soil Chemistry:

B. Physico-Chemical Models, Elsevier, Amsterdam. Chapter 13 (1982).

[18] T. Hiemstra, W.H. van Riemsdijk and G.H. Bolt, "Multisite Proton Adsorption Modeling at the Solid/ Solution Interface of (Hydr)oxides: A New Approach: I. Model Description and Evaluation of Intrinsic Reaction Constants", J. Coll. Interf. Sci., 133, pp. 91-104 (1989).

[19] T. Hiemstra and W.H. van Riemsdijk, "A Surface Structural Approach to Ion Adsorption: The Charge Distribution (CD) Model", J. Colloid Interf. Sci., 179, pp. 488-508 (1996).

[20] Y. Saito, M. Ochs, T. Suyama, A. Kitamura, M. Shibata and H. Sasamoto, An Update of the Sorption Database: Correction and Addition of
Published Literature Data, JAEA-Data/Code 2007014, JAEA (2007).

[21] J. Jung, J.K. Lee and P.S. Hahn, Development and Application of a Sorption Data Base for the Performance Assessment of a Radwaste Repository. Waste Manage., 21, pp. 363-369 (2001).

[22] J.W. Kim, J.H. Kim, H.K. Kim, R.H. Park, S.Y. Park, N.Y. Lee, S.H. Lee and J.H. Lee, Introduction to Statistics, Jungik Publishing Co., Seoul (2001).

[23] T.D. Waite, J.A. Davis, T.E. Payne, G.A. Waychunas and N. Xu, "Uranium(VI) Adsorption to Ferrihydrite: Application of a Surface Complexation Model", Geochim. Cosmochim. Acta, 58, pp. 5465-5478 (1994).

[24] M.H. Baik, S.P. Hyun, W.J. Cho and P.S. Hahn, "Contribution of Minerals to the Sorption of $\mathrm{U}(\mathrm{VI})$ on Granite", Radiochim. Acta, 92, pp. 663-669 (2004).

[25] R. Brandt, T. Schäfer, F. Claret and D. Bosback, "Heterogenous Formation of Ferric Oxide Nanoparticles on Chlorite Surfaces studied by X-ray Absorption Spectromicroscopy (STXM)", Chem. Geol., 329, pp. 42-52 (2012).

[26] T. Murakami and H. Isobe, T. Sato, T. Ohnuki, "Weathering of Chlorite in a Quartz-Chlorite Schist: I. Mineralogical and Chemical Changes", Clay. Clay. Miner., 44, pp. 244-256 (1996).

[27] S. Bachmaf and B.J. Merkel, "Sorption of Uranium(VI) at the Clay Mineral-Water Interface", Environ. Earth Sci., 63, pp. 925-934 (2011).

[28] J.B. Dixon and S.B. Weed, Mineral in Soil Environment. 2nd Ed., Soil Science Society of America, Madison, Wisconsin (1989).

[29] K. Andersson and B. Allard, Sorption of Radionuclides on Geologic Media -A Literature Survey.I. Fission Products. SKB TR-83-07, Svensk Kärnbränslehantering AB., Stockholm (1983).

[30] R. Guillaumont, T. Fanghanel, J. Fuger, I. Grenthe, V. Neck, D.A. Palmer and M.H. Rand, Update on the Chemical Thermodynamics of Uranium, Neptunium, Plutonium, Americium and Technetium, Chemical Thermodynamics Series 5, Elsevier (2003).

[31] J.P. Gustafsson, Visual MINTEQ, Version 3.0, (http:// www.lwr.kth.se/English/OurSoftware/vminteq), Stockholm (2010). 